\title{
Total 25-hydroxyvitamin D but not free 25-hydroxyvitamin $D$ is associated with vitamin $D$ binding globulin in adults with cirrhosis
}

\begin{abstract}
Background: Total 25-hydroxyvitamin D 25(OH)D levels are influenced by vitamin $\mathrm{D}$ binding globulin (VDBG) produced by hepatocytes.

Aim: To determine associations of VDBG with vitamin D measures and associations of total and calculated free $25(\mathrm{OH}) \mathrm{D}$ with albumin corrected calcium and intact parathyroid hormone (iPTH) levels in the setting of cirrhosis.

Methods: Correlation coefficients were calculated between log transformed VDBG and vitamin D measures. Linear regression models were constructed to examine the associations of total and free 25(OH)D levels with albumin corrected serum calcium and $\mathrm{PTTH}$ levels in 40 patients with cirrhosis.

Results: Median age was 60.1 years and cirrhosis was attributed to hepatitis $\mathrm{C}$ in $47.5 \%$, alcohol use in $27.5 \%$, and other in $25.0 \%$. Median total $25(\mathrm{OH}) \mathrm{D}$, calculated free $25(\mathrm{OH}) \mathrm{D}$, and VDBG levels were $18.4(13.1,32.7) \mathrm{ng} / \mathrm{mL}, 10.2(7.4,13.4) \mathrm{pg} /$ $\mathrm{mL}$, and $143.8(106.7,205.2) \mu \mathrm{g} / \mathrm{mL}$, respectively. VDBG showed strong correlations with $25(\mathrm{OH}) \mathrm{D}(\mathrm{r}=0.64 ; \mathrm{P}<0.001)$ but weak correlations with free $25(\mathrm{OH}) \mathrm{D}(\mathrm{r}=0.15$; $\mathrm{P}=0.4)$. Albumin corrected serum calcium showed moderate correlations with total $(\mathrm{r}=0.24 ; \mathrm{P}=0.1)$ and free $25(\mathrm{OH}) \mathrm{D}(\mathrm{r}=0.34 ; \mathrm{P} 0.01)$ but not with VDBG levels $(\mathrm{r}=-$ $0.05 ; \mathrm{P}=0.8$ ). In contrast, iPTH levels showed a weak correlation with $25(\mathrm{OH}) \mathrm{D}$ $(\mathrm{r}=0.14 ; \mathrm{P}=0.4)$ and free $25(\mathrm{OH}) \mathrm{D}(\mathrm{r}=0.02 ; \mathrm{P}=0.9)$. After adjustment for covariates, free $25(\mathrm{OH}) \mathrm{D}$ was significantly associated with albumin corrected serum calcium levels $(\beta=0.005 ; 95 \%$ CI $0.0004,0.009)$ but not with iPTH ( $\beta=-0.006 ; 95 \%$ CI -0.04 , $0.03 ; \mathrm{P}=0.7)$.
\end{abstract}

Conclusion: In adults with cirrhosis, total but not free 25(OH)D is associated with VDBG levels.

Keywords: vitamin D binding globulin, vitamin D, free vitamin D, bioavailable D, cirrhosis, liver disease

\author{
Volume 6 Issue 2 - 2018
}

\author{
Daneyal Syed,' Holly Kramer,' Ramon \\ Durazo-Arvizu, ${ }^{2}$ Pauline Camacho,' Andy \\ Hoofnagle, ${ }^{3}$ Scott Cotler ${ }^{1}$ \\ 'Department of Medicine, Loyola University Medical Center, \\ USA \\ ${ }^{2}$ Department of Public Health Sciences, Loyola University \\ Chicago, USA \\ ${ }^{3}$ Department of Laboratory Medicine, University of Washington \\ School of Medicine, USA
}

\begin{abstract}
Correspondence: Holly Kramer MD MPH, Department of Public Health Sciences, Loyola University Chicago CTRE 454, 2160 S, First Avenue, Maywood, IL 60I53, USA, Tel 708-327-
\end{abstract} 9039, Fax 708216 8296, Email hkramer@lumc.edu

Received: March 04, 2018| Published: April 18, 2018

\section{Introduction}

Cirrhosis is often accompanied by low 25-hydroxyvitamin [25(OH)D] levels $(<20 \mathrm{ng} / \mathrm{ml}),{ }^{1-4}$ which indicates insufficient or deficient vitamin D status. ${ }^{5}$ Inadequate vitamin D status among adults with liver disease may be attributed to multiple factors including lack of liver hydroxylation of calciferol to yield $25(\mathrm{OH}) \mathrm{D}$, low sunlight exposure, malabsorption or other factors. Vitamin D undergoes its first hydroxylation step in the liver, forming $25(\mathrm{OH}) \mathrm{D}$, which is then further hydroxylated to its active form, 1,25 dihydroxyvitamin D $[1,25(\mathrm{OH}) 2 \mathrm{D}]$, primarily in the kidneys. ${ }^{6}$ This active form of vitamin D impacts calcium homeostasis by increasing bone mineralization and intestinal calcium absorption. ${ }^{9,10}$ To prevent accumulation of toxic levels of vitamin D, the gene CYP24A1 encodes an enzyme that catalyzes the 24-hydroxylation of $25(\mathrm{OH}) \mathrm{D}$ and its active form 1,25-dihydroxyvitamin $\mathrm{D}[1,25(\mathrm{OH}) 2 \mathrm{D})$, converting them to inactive forms. ${ }^{6}$

Vitamin D status holds clinical importance in the setting of liver disease because low 25(OH)D levels may negatively impact immune function and bone formation and possibly influence liver disease progression. ${ }^{7-12}$ However, assessment of vitamin D status in the setting of cirrhosis is complicated by the fact that approximately $90 \%$ of 25(OH)D levels circulate bound to VDBG, a protein produced by hepatocytes. ${ }^{13}$ Low levels of $25(\mathrm{OH}) \mathrm{D}$, the major circulating form of vitamin $\mathrm{D}$, may reflect impaired production of VDBG by hepatocytes. $(4,14)$ Free and bioavailable $25(\mathrm{OH}) \mathrm{D}$ have been proposed as alternative measures for assessment of vitamin $\mathrm{D}$ status because free $25(\mathrm{OH}) \mathrm{D}$ circulates unbound while bioavailable circulates free or only weakly bound to albumin. ${ }^{15,16}$ Thus, both free and bioavailable 25(OH)D are not dependent on VDBG production.

Despite low vitamin D levels in patients with liver disease, we and others have previously shown that 25(OH)D levels do not correlate with albumin corrected serum calcium levels in patients with cirrhosis. ${ }^{4,17,18}$ Moreover, hypocalcemia and high intact parathyroid hormone (iPTH) levels are uncommon among adults with cirrhosis and low 25(OH)D levels which suggests that compensatory mechanisms exist. ${ }^{3,4,18,19}$ Previous studies have reported higher levels of free $25(\mathrm{OH}) \mathrm{D}$ in adults with cirrhosis compared to levels in healthy adults and pregnant women. ${ }^{19,20}$ Another alternative measure is the ratio of $24,25(\mathrm{OH}) 2 \mathrm{D} 3$-to-25(OH)D. In the setting of low vitamin D status, inactivation of vitamin D will be low. Higher levels of the ratio $24,25(\mathrm{OH}) 2 \mathrm{D} 3$-to-25(OH)D indicate upregulation of the gene CYP24A1 to prevent vitamin D intoxication. Few studies have examined this ratio, especially in the setting of cirrhosis. In this 
pilot study, we measured VDBG and total 25(OH)D, 1,25(OH)2D and the ratio of $24,25(\mathrm{OH}) 2 \mathrm{D} 3-$ to- $25(\mathrm{OH}) \mathrm{D}$ and calculated free and bioavailable $25(\mathrm{OH}) \mathrm{D}$ in 40 adults with cirrhosis to investigate the associations of VDBG with total, free and bioavailable 25(OH)D and the associations of vitamin D measures with albumin-corrected serum calcium and iPTH levels in patients with cirrhosis.

\section{Methods}

\section{Study population}

This cross-sectional study included patients with cirrhosis receiving care at Loyola University Medical Center, a large, urban academic medical institution. The 40 patients were selected from a cohort study of 456 patients with cirrhosis designed to examine the determinants of liver disease progression. Patients were recruited during a routine clinic visit from August 29, 2013 to January 28, 2015 when clinical, biochemical and radiological tests were performed. Diagnosis of cirrhosis was based on clinical and radiological data or examination of liver histology. We selected 40 participants with a range of modeling end-stage liver disease-sodium (MELD-Na) scores and liver disease due to hepatitis $\mathrm{C}$ and/or alcohol use or nonalcoholic steatohepatitis (NASH), the three most common causes of cirrhosis, and with complete information on serum calcium, albumin, and creatinine measurements. The study was approved by the Loyola University Chicago Institutional Review Board and all patients provided written informed consent.

\section{Vitamin D binding globulin}

Liquid chromatography-mass spectrometry/mass spectrometry (LC-MS/MS) methodology was used to measure VDBG. The lower limit of quantification was $71 \mu \mathrm{g} / \mathrm{ml}$ and the assay was linear from 62 to $434 \mu \mathrm{g} / \mathrm{ml}$ with a CV of 7.3-9.0\%. Mean concentration (standard deviation) in healthy adults using this assay has been reported as $262(25) \mu \mathrm{g} / \mathrm{ml} .^{21}$ Unlike immunoassays, this method does not use antibodies that recognize regions of the protein that may be affected by the genotype of GC which encodes VDBG, a highly polymorphic protein. Thus, the GC genotype does not influence this assay. ${ }^{21}$ In addition; previous validation has demonstrated that bilirubin (conjugated and unconjugated) does not have an effect on the performance of the assay. ${ }^{21}$

\section{Vitamin D and biochemical measures}

Non-fasting blood specimens were collected during a clinic visit and were sent immediately to the Loyola laboratory for measurement of routine clinical measurements. Levels of $25(\mathrm{OH}) \mathrm{D}, 1,25(\mathrm{OH}) 2 \mathrm{D}$ and $24,25(\mathrm{OH}) 2 \mathrm{D} 3$ were measured in serum using immunoaffinity extraction and liquid chromatography/tandem mass spectrometry (LC-MS/MS). Calibration of 25(OH)D was verified using National Institute of Standards Technology (NIST) SRM 972a. Levels of free $25(\mathrm{OH}) \mathrm{D}$ and bioavailable $25(\mathrm{OH}) \mathrm{D}$ were calculated based on previously reported affinity binding constants between $25(\mathrm{OH}) \mathrm{D}$, VDBG, and albumin. ${ }^{22}$ Levels of iPTH were measured in serum using an automated sandwich immunoassay (Beckman Coulter DxI). Levels of iPTH, 25(OH)D, 1,25(OH)2D, 24,25(OH)2D3, and VDBG were measured at the University of Washington Department of Laboratory Medicine, Seattle, Washington Serum albumin, creatinine and total bilirubin levels were measured using a colorimetric method and calcium was measured using indirect ion selective electrodes. Blood reference range values for serum calcium and albumin were 8.5-10.5 $\mathrm{mg} / \mathrm{dl}$ and 3.6-5.0 $\mathrm{g} / \mathrm{dl}$, respectively. The following equation was used to calculate corrected calcium levels: corrected $\mathrm{Ca}(\mathrm{mg} / \mathrm{dl})=$ measured total calcium in $\mathrm{mg} / \mathrm{dl}+[0.8 \times(4-$ albumin in $\mathrm{g} / \mathrm{dl})]$. Serum sodium was measured using an ion specific electrode. Serum albumin, creatinine, total bilirubin, international normalized ratio (INR), and sodium were measured at the Loyola University Medical Center clinical laboratory.

\section{Liver disease severity}

Liver disease severity was assessed with serum albumin levels ${ }^{23}$ and the MELD-Na score. ${ }^{24}$ The original MELD score predicted prognosis in patients with cirrhosis based on kidney function and dialysis requirements, serum bilirubin and the international normalized ratio (INR). In recognition of the independent association between serum sodium and transplant waitlist mortality for patients with cirrhosis, ${ }^{24-28}$ the Organ Procurement and Transplantation Network began incorporating the sodium into the MELD score for prioritizing transplants based on liver disease severity in 2016. ${ }^{29}$ Higher MELD$\mathrm{Na}$ scores indicate increased severity of liver disease.

\section{Disease etiology, demographics}

Information on demographics was obtained using standardized questionnaires, while the primary etiology of liver disease was obtained from the electronic medical record. At the clinic visit, weight was measured without shoes to the nearest $0.1 \mathrm{~kg}$ using a standard balance and height was measured using a stadiometer without shoes. Body mass index (BMI) was calculated as weight in $\mathrm{kg}$ divided by the height in meters squared. Information on vitamin D supplementation, including ergocalciferol or cholecalciferol, and calcium supplementation was obtained from the medication list in the electronic medical record at the time of enrollment.

\section{Statistical analysis}

We used STATA/IC 13.1 (StataCorp LP, College Station, TX, USA) to perform all statistical analyses. Median values (interquartile range) are presented for continuous variables, and frequencies were reported for categorical variables. Scatterplots of serum levels of VDBG vs. MELD-Na scores and serum albumin and vs. vitamin D measures were examined. Pearson correlation coefficients were calculated to quantify the correlation between $\log$ transformed values of VDBG, vitamin D measures and serum albumin corrected calcium and iPTH levels. Linear regression models were then used to examine the factors that account for the variance in log transformed $25(\mathrm{OH})$ $\mathrm{D}$ levels in this sample of adults with liver disease. Models examined demographic factors age, sex, race and body mass index (BMI), serum creatinine levels, and use of vitamin D supplements. These covariates were selected because they may influence vitamin D levels. ${ }^{1,30}$ Linear regression models were also constructed to examine the association of vitamin D measures with log transformed albumin corrected calcium and iPTH levels. The models adjusted for variables selected due to their potential influence on calcium and iPTH levels including age, sex, race, BMI, serum creatinine level, and use of vitamin D or calcium supplements. Regression analyses were repeated after excluding individuals using calcium or vitamin D supplements $(\mathrm{n}=10)$.

\section{Results}

The median age of the 40 adults with cirrhosis was $60.1(55.3-$ $64.7)$ years. The majority $(62.5 \%)$ were white and over half $(52.5 \%)$ were obese (see Table 1). Cirrhosis was attributed to hepatitis $\mathrm{C}$ in 
47.5\%, alcohol use in $27.5 \%$, both hepatitis $\mathrm{C}$ and alcohol use in $17.5 \%$ and NASH in $7.5 \%$. Vitamin D supplementation use was reported by $30 \%$ of patients while only $10.8 \%$ were using calcium supplements. The median MELD-Na score was 13.0 (Interquartile Range [IQR] 9.5-16.5) with a range of 6-30 and median VDBG levels were 142.8 (IQR 106.7-205.2) $\mu \mathrm{g} / \mathrm{ml}$. The median 25(OH)D and $1,25(\mathrm{OH})$ 2D levels were 18.4 (IQR 13.1-32.7) $\mathrm{ng} / \mathrm{ml}$ and 36.4 (IQR 26.6-49.4) $\mathrm{pg} / \mathrm{ml}$, respectively while median free and bioavailable 25(OH)D levels were 10.2 (IQR 7.4, 13.4) pg/mL, and 3.0 (IQR 2.1, 4.2) $\mu \mathrm{g} / \mathrm{mL}$, respectively. The normal reference range for iPTH was $10-65 \mathrm{pg} / \mathrm{ml}$ and the median iPTH level in this group was 25.3 (IQR 18.8-31.3) $\mathrm{pg} / \mathrm{ml}$.

Table I Baseline characteristics of study participants $(n=40)$

\begin{tabular}{|c|c|}
\hline Age (years) & $60.1(55.3-64.7)$ \\
\hline$\%$ Male & $55(n=22)$ \\
\hline \multicolumn{2}{|l|}{ Race } \\
\hline \%White & $62.5(n=25)$ \\
\hline \% Black & $37.5(n=15)$ \\
\hline BMI $\left(\mathrm{kg} / \mathrm{m}^{2}\right)$ & $30.5(24.9,33.8)$ \\
\hline \multicolumn{2}{|l|}{ Cirrhosis etiology } \\
\hline$\% \mathrm{NASH}$ & $7.5(n=3)$ \\
\hline$\%$ ETOH & $27.5(n=11)$ \\
\hline$\% \mathrm{HCV}$ & $47.5(n=19)$ \\
\hline \% $\mathrm{ETOH}$ and $\mathrm{HCV}$ & $17.5(n=7)$ \\
\hline MELD-Na & $13.0(9.5-16.5)$ \\
\hline Intact parathyroid hormone $(\mathrm{pg} / \mathrm{mL})$ & $25.3(|8.8-3| .3)$ \\
\hline *Calcium (mg/dL) & $9.54(9.23-9.84)$ \\
\hline Albumin (g/dL) & $3.2(2.8-3.8)$ \\
\hline Serum creatinine (mg/dl) & $0.86(0.72-1.00)$ \\
\hline 25-hydroxyvitamin D (ng/ml) & I8.4 (I3.I-32.7) \\
\hline $\mathrm{I}, 25(\mathrm{OH})_{2} \mathrm{D}(\mathrm{pg} / \mathrm{mL})$ & $36.4(26.6-49.4)$ \\
\hline $24,25(\mathrm{OH})_{2} \mathrm{D}_{3}(\mathrm{ng} / \mathrm{ml})$ & $0.7 \mid(0.3|-| .29)$ \\
\hline Ratio $24,25(\mathrm{OH})_{2} \mathrm{D}_{3}$-to-total $25(\mathrm{OH}) \mathrm{D}$ & $0.04(0.02-0.06)$ \\
\hline Vitamin D binding globulin $(\mu \mathrm{g} / \mathrm{mL})$ & I $43.8(106.7-205.2)$ \\
\hline Free $25(\mathrm{OH}) \mathrm{D}(\mathrm{pg} / \mathrm{mL})$ & $10.2(7.4,13.4)$ \\
\hline Bioavailable 25(OH)D ( $\mu \mathrm{g} / \mathrm{mL})$ & $3.0(2.1,4.2)$ \\
\hline \% Using vitamin D supplements & $30.0(n=12)$ \\
\hline$\%$ Using calcium supplements & $10.8(n=4)$ \\
\hline
\end{tabular}

Data presented as median (interquartile range) or \%. Free vitamin D and bioavailable $D$ are calculated based on affinity constants for $25(\mathrm{OH}) \mathrm{D}$ and VDBG and albumin reported by Bikle et al. ${ }^{20}$

Abbreviations: BMI, body mass index; $25(\mathrm{OH}) \mathrm{D}, 25$-hydroxyvitamin $\mathrm{D}$; I,25(OH)2D, I,25-dihydroxyvitamin D;24,25(OH) D3, 24,25 dihydroxyvitamin D3; MELD-Na, modeling end-stage liver disease score; NASH, non-alcohol steatohepatitis; $\mathrm{ETOH}$, alcoholic liver disease; $\mathrm{HCV}$, hepatitis $\mathrm{C}$ virus, ${ }^{*} \mathrm{Calcium}$ is adjusted for serum albumin levels.

Figure 1 shows the scatter plots of VDBG by MELD-Na scores and by serum albumin levels. The upper figure with MELD-Na score on the horizontal axis shows an outlier with a VDBG of $220 \mu \mathrm{g} / \mathrm{ml}$ and a MELD-Na score of 28. This patient had a serum total bilirubin level of $0.8 \mathrm{mg} / \mathrm{dl}$ and an INR of 1.21 and serum albumin level of 3.1 $\mathrm{mg} / \mathrm{dl}$. However, the serum creatinine was $8.58 \mathrm{mg} / \mathrm{dl}$ which raised the MELD-Na score. The next highest creatinine value in the study population was 2.25 and the majority of patients had serum creatinine values $<1.0 \mathrm{mg} / \mathrm{dl}$. VDBG was strongly and significantly correlated with both MELD-Na $(\mathrm{r}=-0.51 ; \mathrm{P}<0.001)$ and serum albumin levels $(\mathrm{r}=0.54 ; \mathrm{P}<0.001)$. After excluding the patient with a serum creatinine of $8.58 \mathrm{mg} / \mathrm{dl}$, the correlation coefficients between VDBG and MELD$\mathrm{Na}$ scores $(\mathrm{r}=-0.62 ; \mathrm{P}<0.001)$ and serum albumin $(\mathrm{r}=0.55 ; \mathrm{P}<$ 0.001 ) were somewhat stronger. Figure 2 shows the scatterplots of the vitamin D measures by VDBG levels. Fairly linear distributions were noted between 25(OH)D and 1,25(OH)2D and VDBG levels. Table 2 shows the correlations between the log transformed VDBG and vitamin D measures, albumin, calcium and iPTH levels. Strong and significant correlations were noted between VDBG and 25(OH)D $(\mathrm{r}=$ $0.64 ; \mathrm{P}<0.001)$ and $1,25(\mathrm{OH}) 2 \mathrm{D}(\mathrm{r}=0.53 ; \mathrm{P}<0.001)$ while weaker correlations were noted between VDBG and free $(\mathrm{r}=0.15 ; \mathrm{P}=0.4)$ and bioavailable 25(OH)D $(\mathrm{r}=0.34 ; \mathrm{P}=0.06)$. Albumin corrected serum calcium showed moderate correlations with total $(\mathrm{r}=0.24 ; \mathrm{P}=0.1)$, free $(\mathrm{r}=0.34 ; \mathrm{P} 0.01)$ and bioavailable $25(\mathrm{OH}) \mathrm{D}(\mathrm{r}=0.29 ; \mathrm{P}=0.07)$ while iPTH levels showed moderate correlations only with VDBG $(\mathrm{r}=-0.22 ; \mathrm{P}=0.1)$ and the ratio of $24,25(\mathrm{OH}) 2 \mathrm{D} 3-\mathrm{to}-25(\mathrm{OH}) \mathrm{D}(\mathrm{r}=$ $-0.29 ; \mathrm{P}=0.07)$. Results did not change substantially after excluding individuals receiving vitamin $\mathrm{D}$ or calcium supplements.

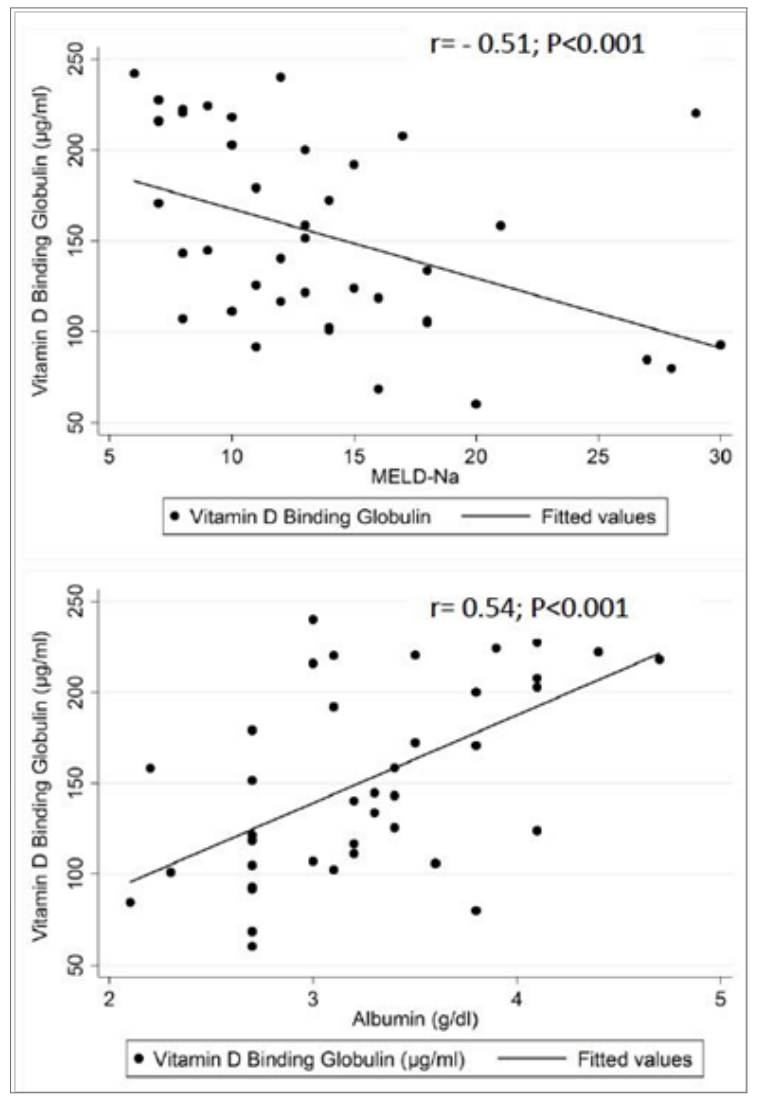

Figure I Scatterplots of vitamin D binding globulin by modeling end-stage liver diseae sodium (MELD-Na) scores (top) and by serum albumin levels (bottom) in 40 adults with cirrhosis. 
The results of the linear regression analyses with log transformed $25(\mathrm{OH}) \mathrm{D}$ as the dependent variable are shown in Table 3. VDBG levels alone accounted for $41 \%$ of the variance in $25(\mathrm{OH}) \mathrm{D}$ levels. The addition of demographic variables and use of vitamin D supplements did not substantially increase the $\mathrm{R}^{2}$ value. The only variable significantly associated with log transformed $25(\mathrm{OH}) \mathrm{D}$ level was VDBG. Findings did not change after excluding the 10 individuals using calcium or vitamin D supplements which included the one patient with a serum creatinine of $8.58 \mathrm{mg} / \mathrm{dl}$.

Table 2 Pearson correlation matrix of log transformed measures of vitamin $D$, parathyroid hormone, and calcium levels in adults with liver disease ( $=40$ ) and after excluding users of vitamin $D$ or calcium supplements $(n=30)$

\begin{tabular}{|c|c|c|c|c|c|c|c|c|}
\hline Total sample $(n=40)$ & & & & & & & & \\
\hline & VDBG & $25(\mathrm{OH}) \mathrm{D}$ & $\mathrm{I}, 25(\mathrm{OH})_{2} \mathrm{D}$ & $\begin{array}{l}\text { Free } \\
25(\mathrm{OH}) \mathrm{D}\end{array}$ & $\begin{array}{l}\text { Bioavail } \\
25(\mathrm{OH}) \mathrm{D}\end{array}$ & $\begin{array}{l}24,25(\mathrm{OH})_{2} \mathrm{D}_{3} \text {-to- } \\
25(\mathrm{OH}) \mathrm{D}\end{array}$ & Calcium & iPTH \\
\hline VDBG & 1.0 & & & & & & & \\
\hline $25(\mathrm{OH}) \mathrm{D}$ & $0.64 *$ & 1.0 & & & & & & \\
\hline $\mathrm{I}, 25(\mathrm{OH})_{2} \mathrm{D}$ & $0.53^{*}$ & $0.40+$ & 1.0 & & & & & \\
\hline Free $25(\mathrm{OH}) \mathrm{D}$ & 0.15 & $0.86 *$ & 0.16 & 1.0 & & & & \\
\hline Bioavail $25(\mathrm{OH}) \mathrm{D}$ & 0.34 & $0.91 *$ & 0.26 & $0.93^{*}$ & 1.0 & & & \\
\hline $\begin{array}{l}24,25(\mathrm{OH})_{2} \mathrm{D} \text {-to-25 }(\mathrm{OH}) \\
\mathrm{D}_{3}\end{array}$ & 0.33 & 0.30 & 0.25 & 0.15 & 0.26 & 1.0 & & \\
\hline Calcium & -0.05 & 0.24 & -0.10 & $0.34+$ & 0.29 & -0.04 & 1.0 & \\
\hline ¡PTH & -0.22 & 0.14 & 0.07 & 0.02 & -0.05 & -0.29 & -0.22 & 1.0 \\
\hline \multicolumn{9}{|c|}{ Non-users of vitamin D or calcium supplements $(n=30)$} \\
\hline & VDBG & $25(\mathrm{OH}) \mathrm{D}$ & $\mathrm{I}, 25(\mathrm{OH})_{2} \mathrm{D}$ & $\begin{array}{l}\text { Free } \\
25(\mathrm{OH}) \mathrm{D}\end{array}$ & $\begin{array}{l}\text { Bioavail } \\
25(\mathrm{OH}) \mathrm{D}\end{array}$ & $\begin{array}{l}24,25(\mathrm{OH})_{2} \mathrm{D}_{3} \text {-to- } \\
25(\mathrm{OH}) \mathrm{D}\end{array}$ & Calcium & iPTH \\
\hline VDBG & 1.0 & & & & & & & \\
\hline $25(\mathrm{OH}) \mathrm{D}$ & $0.65^{*}$ & 1.0 & & & & & & \\
\hline $\mathrm{I}, 25(\mathrm{OH})_{2} \mathrm{D}$ & $0.65^{*}$ & $0.36+$ & 1.0 & & & & & \\
\hline Free $25(\mathrm{OH}) \mathrm{D}$ & 0.16 & $0.86^{*}$ & 0.23 & 1.0 & & & & \\
\hline Bioavail $25(\mathrm{OH}) \mathrm{D}$ & $0.35+$ & $0.91 *$ & $0.34+$ & $0.93^{*}$ & 1.0 & & & \\
\hline $\begin{array}{l}24,25(\mathrm{OH})_{2} \mathrm{D}_{3} \text {-to- } \\
25(\mathrm{OH}) \mathrm{D}\end{array}$ & $0.42+$ & 0.34 & 0.21 & 0.14 & 0.29 & 1.0 & & \\
\hline †Calcium & -0.03 & $0.33+$ & -0.20 & $0.39+$ & $0.38+$ & -0.05 & 1.0 & \\
\hline
\end{tabular}

†Calcium, measured total calcium in $\mathrm{mg} / \mathrm{dL}=[0.8 \times(4-$ albumin in $\mathrm{g} / \mathrm{dL})]$.

Abbreviations:VDBG, vitamin D binding globulin; 25(OH)D, 25-hydroxyvitamin D; I,25(OH)2D, I,25-dihydroxyvitamin D; Free D, 25(OH)D not bound to or albumin; Bioavail $25(\mathrm{OH}) \mathrm{D}$, bioavailable $25(\mathrm{OH}) \mathrm{D}$ that is free or weakly bound to albumin;VDBG, vitamin $\mathrm{D}$ binding $\mathrm{Protein}$; $24,25(\mathrm{OH}){ }_{2} \mathrm{D}$, 24,25-dihydroxyvitamin D; iPTH, intact parathyroid hormone level; *P $<0.00$ I; + P $<0.05$

Table 3 Results of linear regression analyses with log transformed 25-hydroxyvitamin D levels as dependent variable

\begin{tabular}{|c|c|c|c|c|c|c|}
\hline & Model I & & & Model 2 & & \\
\hline \multicolumn{7}{|l|}{ Total sample $(n=40)$} \\
\hline & & $\mathrm{R}^{2}$ & PValue & & $\mathrm{R}^{2}$ & PValue \\
\hline $\begin{array}{l}\text { Vitamin D binding globulin } \\
\text { (per unit increase) }\end{array}$ & $0.01(0.005,0.01)$ & $0.4 \mathrm{I}$ & $<0.001$ & $0.01(0.005,0.01)$ & 0.44 & $<0.001$ \\
\hline Age (per year increase) & $0.01(-0.01,0.04)$ & 0.03 & 0.3 & $-0.01(-0.03,0.02)$ & & 0.7 \\
\hline Male vs. female & $-0.29(-0.70,0.11)$ & 0.05 & 0.2 & $-0.22(-0.56,0.12$ & & 0.2 \\
\hline White race vs. non-white race & $-0.33(-0.74,0.09)$ & 0.06 & 0.1 & $0.03(-0.40,0.46)$ & & 0.9 \\
\hline BMI (per kg/m² increase) & $0.004(-0.02,0.03)$ & 0.002 & 0.8 & $0.01(-0.02,0.03)$ & & 0.5 \\
\hline $\begin{array}{l}\text { Vitamin D supplementation vs. } \\
\text { no supplementation }\end{array}$ & $0.10(-0.35,0.55)$ & 0.01 & 0.7 & $-0.08(-0.05,0.36)$ & & 0.7 \\
\hline
\end{tabular}

Non-users of Vitamin D or Calcium supplements $(n=30)$ 


\begin{tabular}{|c|c|c|c|c|c|c|}
\hline & Model I & & & Model 2 & & \\
\hline $\begin{array}{l}\text { Vitamin D binding globulin } \\
\text { (per unit increase) }\end{array}$ & $0.0 \mathrm{I}(0.006,0.0 \mathrm{I})$ & 0.51 & $<0.001$ & $0.0 \mathrm{I}(0.004,0.0 \mathrm{I})$ & 0.58 & 0.001 \\
\hline Age (per year increase) & $0.01(-0.02,0.05)$ & 0.04 & 0.3 & $-0.01(-0.03,0.02)$ & & 0.6 \\
\hline Male vs. female & $-0.55(-1.11,0.02$ & 0.13 & 0.06 & $-0.40(-0.86,0.06)$ & & 0.09 \\
\hline White race vs. non-white race & $-0.53(-1.17,0.10)$ & 0.10 & 0.10 & $-0.17(-0.73,0.39)$ & & 0.6 \\
\hline BMI (per kg/m² increase) & $0.003(-0.05,0.06)$ & 0.00 & 0.9 & $-0.002(-0.04,0.04)$ & & 0.9 \\
\hline
\end{tabular}

Model I is unadjusted; Model 2 is mutually adjusted for all variables in table.

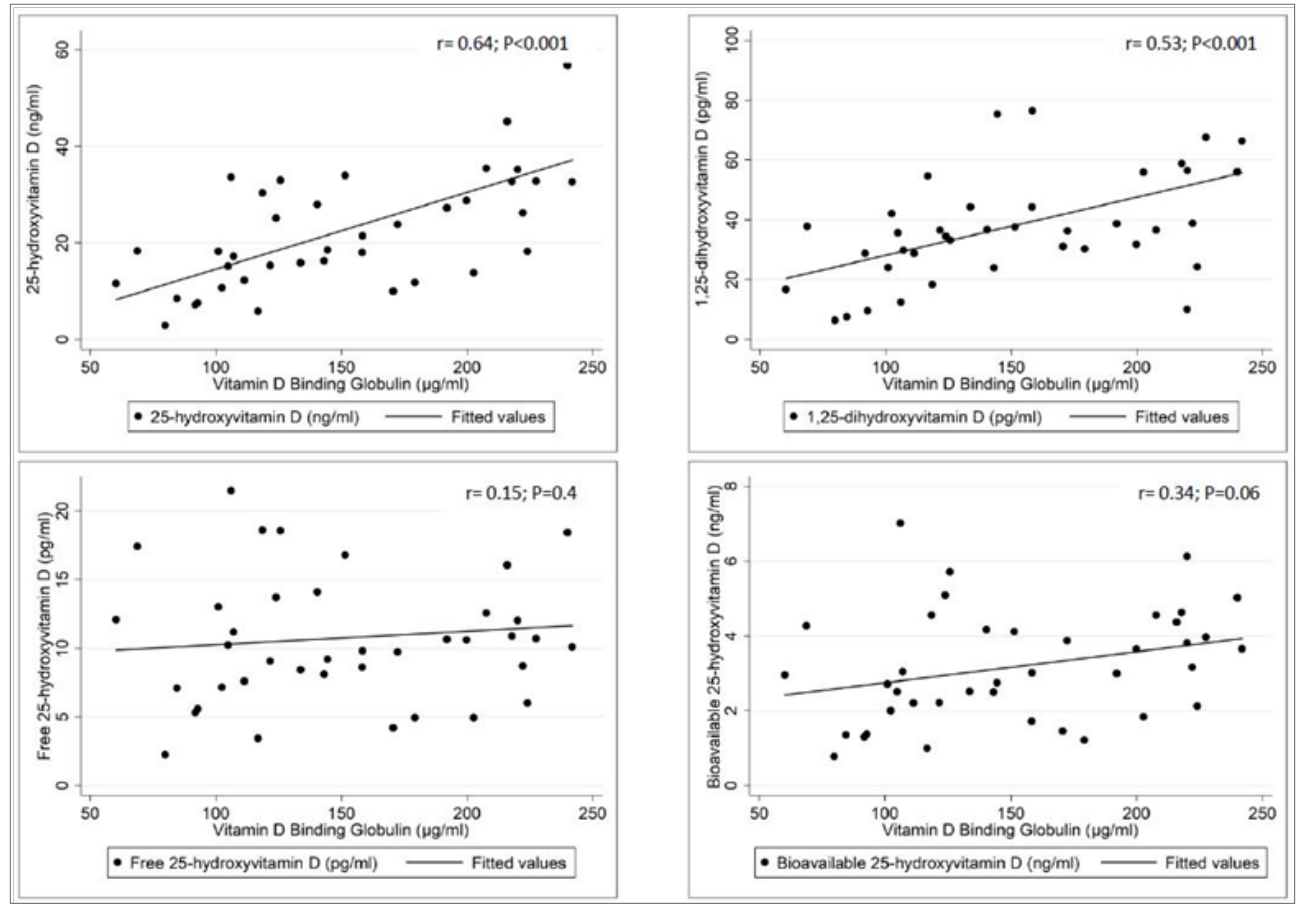

Figure 2 Scatterplots of 25-hydroxyvitamin D [25(OH)D] (upper left), I,25-dihydroxyvitamin D [1,25(OH)2D (upper right), free 25-hydroxyvitamin D (bottom left) and bioavailable 25-hydroxyvitamin D (bottom right) vs. vitamin D binding globulin levels in 40 adults with cirrhosis.

Table 4 shows the associations of vitamin D measures with albumin corrected serum calcium levels. In both unadjusted and adjusted models, only free and bioavailable $25(\mathrm{OH}) \mathrm{D}$ were significantly associated with albumin corrected serum calcium levels. Results did not change after excluding individuals using calcium or vitamin D supplements. In contrast, no vitamin D measure was significantly associated with iPTH levels after adjusting for covariates (Table 5).

Table 4 Unadjusted (Model I) and adjusted (Model 2) associations of vitamin D measures with log transformed serum calcium levels in adults with cirrhosis

\begin{tabular}{|c|c|c|c|c|c|c|}
\hline & Model I & & & Model 2 & & \\
\hline \multicolumn{7}{|l|}{ Total Sample $(n=40)$} \\
\hline & & $\mathrm{R}^{2}$ & PValue & & $\mathrm{R}^{2}$ & PValue \\
\hline $\begin{array}{l}\text { Free } 25(\mathrm{OH}) \mathrm{D} \\
\text { (per unit increase) }\end{array}$ & $0.004(0.00 \mathrm{I}, 0.0 \mathrm{I}$ & 0.12 & 0.03 & $0.005(0.0004,0.01)$ & 0.29 & 0.03 \\
\hline $\begin{array}{l}\text { Bioavailable } 25(\mathrm{OH}) \mathrm{D} \\
\text { (per unit increase) }\end{array}$ & $0.01(0.002,0.03)$ & 0.13 & 0.03 & $0.01(0.0004,0.03)$ & 0.28 & 0.04 \\
\hline $\begin{array}{l}25(\mathrm{OH}) \mathrm{D} \\
\text { (per unit increase) }\end{array}$ & $0.001(-0.001,0.002)$ & 0.04 & 0.2 & $0.001(-0.001 .0 .002)$ & 0.20 & 0.3 \\
\hline $\begin{array}{l}\mathrm{I}, 25(\mathrm{OH})_{2} \mathrm{D} \\
\text { (per unit increase) }\end{array}$ & $-0.0002(-0.00 \mathrm{I}, 0.00 \mathrm{I})$ & 0.01 & 0.6 & $-0.00(-0.000 \mathrm{I}, 0.00 \mathrm{I})$ & 0.20 & 0.8 \\
\hline $\begin{array}{l}24,25(\mathrm{OH})_{2} \mathrm{D}_{3} \text {-to- } 25(\mathrm{OH}) \mathrm{D} \\
\text { (per unit increase) }\end{array}$ & $-0.21(-1.05,0.62)$ & 0.01 & 0.6 & $-0.28(-1.33,0.76)$ & 0.16 & 0.6 \\
\hline
\end{tabular}


Table continued...

\begin{tabular}{|c|c|c|c|c|c|c|}
\hline & Model I & & & Model 2 & & \\
\hline \multicolumn{7}{|c|}{ Non-users of Vitamin D or Calcium supplements $(n=30)$} \\
\hline $\begin{array}{l}\text { Free } 25(\mathrm{OH}) \mathrm{D} \\
\text { (per unit increase) }\end{array}$ & $0.01(0.0004,0.01)$ & 0.17 & 0.03 & $0.004(-0.001,0.01)$ & 0.23 & 0.08 \\
\hline $\begin{array}{l}\text { Bioavailable } 25(\mathrm{OH}) \mathrm{D} \\
\text { (per unit increase) }\end{array}$ & $0.02(0.004,0.03)$ & 0.21 & 0.01 & $0.02(0.001,0.03)$ & 0.26 & 0.04 \\
\hline $\begin{array}{l}25(\mathrm{OH}) \mathrm{D} \\
\text { (per unit increase) }\end{array}$ & $0.00 \mathrm{I}(-0.00 \mathrm{I}, 0.003)$ & 0.05 & 0.3 & $0.0009(-0.001,0.003)$ & 0.14 & 0.4 \\
\hline $\mathrm{I}, 25(\mathrm{OH})_{2} \mathrm{D}$ (per unit increase) & $-0.0004(-0.002,0.001)$ & 0.02 & 0.5 & $-0.0004(-0.002,0.001)$ & 0.13 & 0.6 \\
\hline $\begin{array}{l}24,25(\mathrm{OH})_{2} \mathrm{D}_{3} \text {-to- } 25(\mathrm{OH}) \mathrm{D} \\
\text { (per unit increase) }\end{array}$ & $-0.28(-1.47,0.92)$ & 0.009 & 0.6 & $-0.36(-1.58,0.87)$ & 0.13 & 0.6 \\
\hline
\end{tabular}

Model I is unadjusted; Model 2 adds age, sex, race, body mass index (BMI), serum creatinine and use of vitamin D or calcium supplements (in total sample only);

Table 5 Unadjusted (Model I) and adjusted (Model 2) associations of vitamin D measures with log transformed intact parathyroid hormone levels in adults with cirrhosis

\begin{tabular}{|c|c|c|c|c|c|c|}
\hline & Model I & & & Model 2 & & \\
\hline \multicolumn{7}{|l|}{ Total Sample $(n=40)$} \\
\hline & & $\mathrm{R}^{2}$ & PValue & & $\mathrm{R}^{2}$ & PValue \\
\hline Free $25(\mathrm{OH}) \mathrm{D}$ & $0.008(-0.03,0.04)$ & 0.06 & 0.7 & $-0.006(-0.04,0.03)$ & 0.39 & 0.7 \\
\hline Bioavailable $25(\mathrm{OH}) \mathrm{D}$ & $-0.007(-0.12,0.11)$ & 0.0003 & 0.9 & $-0.03(-0.14,0.08)$ & 0.39 & 0.6 \\
\hline $25(\mathrm{OH}) \mathrm{D}$ & $0.01(-0.002,0.02)$ & 0.06 & 0.1 & $0.004(-0.01,0.02)$ & 0.39 & 0.5 \\
\hline $\mathrm{I}, 25(\mathrm{OH})_{2} \mathrm{D}$ & $0.002(-0.006,0.01)$ & 0.6 & 0.01 & $0.001(-0.01,0.01)$ & 0.39 & 0.9 \\
\hline $24,25(\mathrm{OH})_{2} \mathrm{D}_{3}$-to- $25(\mathrm{OH}) \mathrm{D}$ & $-7.50(-14.83,-0.17)$ & 0.10 & 0.05 & $-5.61(-14.04,2.82)$ & 0.42 & 0.2 \\
\hline \multicolumn{7}{|c|}{ Non-users of Vitamin D or Calcium supplements $(n=30)$} \\
\hline Free $25(\mathrm{OH}) \mathrm{D}$ & $0.02(-0.03,0.06)$ & 0.03 & 0.4 & $-0.003(-0.05,0.04)$ & 0.38 & 0.9 \\
\hline Bioavailable $25(\mathrm{OH}) \mathrm{D}$ & $0.04(-0.11,0.18)$ & 0.01 & 0.6 & $-0.02(-0.16,0.13)$ & 0.39 & 0.8 \\
\hline $25(\mathrm{OH}) \mathrm{D}$ & $0.01(-0.00 I, 0.03)$ & 0.13 & 0.06 & $0.005(-0.01,0.02)$ & 0.39 & 0.6 \\
\hline $\mathrm{I}, 25(\mathrm{OH})_{2} \mathrm{D}$ & $0.003(-0.01,0.01)$ & 0.01 & 0.6 & $-0.001(-0.01,0.01)$ & 0.38 & 0.8 \\
\hline $24,25(\mathrm{OH})_{2} \mathrm{D}_{3}$-to-25(OH)D & $-6.23(-17.16,4.6 I)$ & 0.05 & 0.2 & $-4.92(-|4.55,4.7|)$ & 0.41 & 0.3 \\
\hline
\end{tabular}

Model I is unadjusted; Model 2 adds age, sex, race, body mass index (BMI), serum creatinine and use of vitamin $\mathrm{D}$ and calcium supplements (in total sample only).

\section{Discussion}

This pilot study shows that VDBG levels are quite low in adults with cirrhosis and levels correlate with liver disease severity as assessed by the MELD-Na score. Our findings are supported by a previous study demonstrating low VDBG levels in adults awaiting liver transplant. ${ }^{4}$ The main role of VDBG is to be the primary carrier protein of both $25(\mathrm{OH}) \mathrm{D}$ and $1,25(\mathrm{OH}) 2 \mathrm{D} .{ }^{31}$ The $25(\mathrm{OH}) \mathrm{D}$ measured clinically reflects levels bound to VDBG and albumin with over $90 \%$ of the $25(\mathrm{OH}) \mathrm{D}$ bound to VDBG. Thus, in the setting of cirrhosis where VDBG production by hepatocytes is impaired, low 25(OH)D levels may not necessarily reflect vitamin D status. The strong correlation observed between serum levels of $25(\mathrm{OH}) \mathrm{D}$ and VDBG complicates assessment of vitamin D status in patients with advanced liver disease. We noted that VDBG was strongly correlated with total $25(\mathrm{OH}) \mathrm{D}$ levels but not with free $25(\mathrm{OH}) \mathrm{D}$. In addition, VDBG showed only a moderate correlation with bioavailable $25(\mathrm{OH})$ D levels. In addition, only free and bioavailable 25(OH)D levels were significantly associated with albumin corrected serum calcium levels in these patients with cirrhosis. While more studies are needed to determine the optimal measures of vitamin D status in adults with advanced liver disease, the findings from this study and others ${ }^{19,20,32,33}$ suggest that calculating or measuring free or bioavailable $25(\mathrm{OH})$ $\mathrm{D}$ may provide additional information regarding vitamin $\mathrm{D}$ status in adults with liver disease, especially when disease is severe and VDBG levels are consequently low. We noted no association of vitamin D measures with iPTH levels consistent with previous studies. ${ }^{34-36}$ Among adults with non-cholestatic liver disease, iPTH levels are usually normal or even low despite low vitamin D levels reflecting the multiplicity of factors that influence bone turnover in the setting of liver disease including alcohol use, estrogen and testosterone levels and malnutrition. ${ }^{35}$

Our study has several limitations. First, the sample size was small and we selected patients across a spectrum of liver disease severity. Bioavailable and free 25(OH)D levels were calculated and not directly measured and calculated values may overestimate circulating free $25(\mathrm{OH}) \mathrm{D}$ levels. ${ }^{19}$ This study is also cross-sectional and cannot 
examine changes in vitamin D or VDBG levels as liver disease progresses. However, one previous study has shown that VDBG levels increase after liver transplantation. ${ }^{4}$ This study used an LC-MS/ MS methodology to measure VDBG levels and this method avoids issues regarding the highly polymorphic nature of VDBG.(21) Assays that utilize antibodies directed against regions of VDBG that are polymorphic may yield erroneous values depending on the genotype. We used a method developed by Henderson, et al. that is independent of the VDBG isoform. ${ }^{21}$ In addition, calibration of vitamin D was verified using a NIST standard.

\section{Conclusion}

In summary, we show that VDBG levels correlate with liver disease severity. Levels of VDBG are also associated with total 25(OH)D and account for a substantial proportion of total $25(\mathrm{OH}) \mathrm{D}$ levels in adults with cirrhosis. In contrast, free and bioavailable $25(\mathrm{OH}) \mathrm{D}$ levels may not be influenced by VDBG levels, are associated with serum calcium levels and may be a useful alternative measure of vitamin D status in adults with liver disease. More studies are needed to determine the optimal measure of vitamin D status in adults with cirrhosis and low levels of VDBG.

\section{Acknowledgements}

The authors thank the participants of the liver disease cohort study conducted at Loyola University Chicago Medical Center. The findings from this study were presented in a poster at the Endocrine Society Meeting March 18, 2018 in Chicago, IL (DS).

\section{Author contributions}

HK and DS developed study design, analyzed data and cowrote manuscript. RD assisted with study design, data analysis and manuscript revisions; PC assisted with data analysis and manuscript revision, $\mathrm{SC}$ enrolled participants in study, obtained serum specimens, and assisted with manuscript revisions. $\mathrm{AH}$ assisted with manuscript revision and interpretation of the data.

\section{Financial support} Center.

Internal funding mechanisms through Loyola University Medical

\section{Disclosure summary}

Authors have no conflicts of interest to report.

\section{References}

1. Stokes CS, Volmer DA, Grunhage F, et al. Vitamin D in chronic liver disease. Liver International. 2013;33(3):338-352.

2. Arteh J, Narra S, Nair S. Prevalence of vitamin D deficiency in chronic liver disease. Dig Dis Sci. 2010;55(9):2624-2628.

3. Fisher L, Fisher A. Vitamin D and parathyroid hormone in outpatients with noncholestatic chronic liver disease. Clin Gastroenterol Hepatol. 2007;5(4):513-520.

4. Reese PP, Bloom RD, Feldman HI, et al. Changes in vitamin D binding protein and vitamin $\mathrm{D}$ concentrations associated with liver transplantation. Liver Int. 2012;32(2):287-296.

5. https://www.ncbi.nlm.nih.gov/books/NBK56070/

6. Bikle DD. Vitamin D metabolism, mechanism of action, and clinical applications. Chem Biol. 2014;21(3):319-329.
7. Targher G, Byrne CD. Lower 25 -hydroxyvitamin D3 levels and increased risk of liver diseases: Is there a causal link? Endocrine. 2014;47(1):3-4.

8. Targher G, Bertolini L, Scala L, et al. Associations between serum 25-hydroxyvitamin D3 concentrations and liver histology in patients with non-alcoholic fatty liver disease. Nutr Metab Cardiovasc Dis. 2007;17(7):517-524.

9. Baur K, Mertens JC, Schmitt J, et al. Swiss Hepatitis C Cohort Study Group 2012 Combined effect of 25-OH vitamin D plasma levels and genetic vitamin D receptor (NR 1I1) variants on fibrosis progression rate in HCV patients. Liver Int. 2012;32(4):635-643.

10. Kitson MT, Roberts SK. D-livering the message: The importance of vitamin D status in chronic liver disease. J Hepatol. 2012;57(4):897-909.

11. Abramovitch S, Dahan-Bachar L, Sharvit E, et al. Vitamin D inhibits proliferation and profibrotic marker expression in hepatic stellate cells and decreases thioacetamide-induced liver fibrosis in rats. Gut. 2011; 60(12):1728-1737.

12. Nelson JE, Roth CL, Wilson LA, et al. Vitamin D deficiency is associated with increased risk of non-alcoholic steatohepatitis in adults with nonalcoholic fatty liver disease: Possible role for MAPK and NF-kappaB? Am J Gastroenterol. 2016;111(6):852-886.

13. Berg JP. Vitamin D-binding protein prevents vitamin D deficiency and presents vitamin D for its renal activation. Eur $J$ Endocrinol. 1999;141(4):321-322.

14. Powe CE, Karumanchi SA, Thadhani R. Vitamin D-binding protein and vitamin D in blacks and whites. N Engl J Med. 2014;370(9):880-881.

15. Chun RF, Peercy BE, Orwoll ES, et al. Vitamin D and DBP: The free hormone hypothesis revisited. J Steroid Biochem Mol Biol. 2014;144 Pt A:132-137.

16. Tsuprykov $\mathrm{O}$, Chen $\mathrm{X}$, Hocher $\mathrm{CF}$, et al. Why should we measure free 25(OH) vitamin D? J Steroid Biochem Mol Biol. 2017;pii: S09600760(17)30364-3.

17. Rech MA, Von Roenn N, Durazo-Arvizu R, et al. Vitamin D levels are associated with liver disease severity in patients with cirrhosis. $J$ Renal and Hepatic Disorders. 2017;1(2):1-9.

18. Corey RL, Whitaker MD, Crowell MD, et al. Vitamin D deficiency, parathyroid hormone levels, and bone disease among patients with end-stage liver disease and normal serum creatinine awaiting liver transplantation. Clin Transplant. 2014;28(5):579-584.

19. Schwartz JB, Lai J, Lizaola B, et al. A comparison of measured and calculated free $25(\mathrm{OH})$ vitamin D levels in clinical populations. $J$ Clin Endocrinol Metab. 2014;99(5):1631-1637.

20. Bikle DD, Halloran BP, Gee E, et al. Free 25-hydroxyvitamin D levels are normal in subjects with liver disease and reduced total 25-hydroxyvitamin D levels. J Clin Invest. 1986;78(3):748-752.

21. Henderson CM, Lutsey PL, Misialek JR, et al. Measurement by a novel LC-MS/MS methodology reveals similar serum concentrations of vitamin D-binding protein in blacks and whites. Clin Chem. 2016;62(1):179-187.

22. Bikle DD, Gee E, Halloran B, et al. Assessment of the free fraction of 25-hydroxyvitamin $\mathrm{D}$ in serum and its regulation by albumin and the vitamin D-binding protein. J Clin Endocrinol Metab. 1986;63(4):954959.

23. Ripoll C, Bari K, Garcia-Tsao G. Serum albumin can identify patients with compensated cirrhosis with a good prognosis. J Clin Gastroenterol. 2015;49(7):613-619.

24. Biggins SW, Kim WR, Terrault NA, et al. Evidence-based incorporation of serum sodium concentration into MELD. Gastroenterology. 2006;130(6):1652-1660. 
25. Ruf AE, Kremers WK, Chavez LL, et al. Addition of serum sodium into the MELD score predicts waiting list mortality better than MELD alone. Liver Transpl. 2005;11(3):336-343.

26. Londono MC, Cardenas A, Guevara M, et al. MELD score and serum sodium in the prediction of survival of patients with cirrhosis awaiting liver transplantation. Gut. 2007;56(9):1283-1290.

27. Marroni CP, de Mello Brandao AB, Hennigen AW, et al. Liver Transplantation Group 2012 MELD scores with incorporation of serum sodium and death prediction in cirrhotic patients on the waiting list for liver transplantation: A single center experience in southern brazil. Clin Transplant. 2012;26(4):E395-E401.

28. Umemura T, Shibata S, Sekiguchi T, et al. Serum sodium concentration is associated with increased risk of mortality in patients with compensated liver cirrhosis. Hepatol Res. 2015;45(7):739-744.

29. Elwir S, Lake J. Current status of liver allocation in the United States. Gastroenterol Hepatol (NY). 2016;12(3):166-170.

30. Holick MF. Vitamin D deficiency. N Engl J Med. 2007;357(3):266-281.
31. Berg JP. Vitamin D-binding protein prevents vitamin D deficiency and presents vitamin D for its renal activation. Eur J Endocrinol. 1999;141(4):321-322.

32. Schwartz JB, Lai J, Lizaola B, et al. Variability in free $25(\mathrm{OH})$ vitamin D levels in clinical populations. J Steroid Biochem Mol Biol. 2014;144(Pt A):156-158.

33. Lai JC, Bikle DD, Lizaola B, et al. Total $25(\mathrm{OH})$ vitamin $\mathrm{D}$, free $25(\mathrm{OH})$ vitamin $\mathrm{D}$ and markers of bone turnover in cirrhotics with and without synthetic dysfunction. Liver Int. 2015;35(10):2294-2300.

34. Miroliaee A, Nasiri-Toosi M, Khalilzadeh O, et al. Disturbances of parathyroid hormone-vitamin D axis in non-cholestatic chronic liver disease: A cross-sectional study. Hepatol Int. 2010;4(3):634-640.

35. Monegal A, Navasa M, Guanabens N, et al. Osteoporosis and bone mineral metabolism disorders in cirrhotic patients referred for orthotopic liver transplantation. Calcif Tissue Int. 1997;60(2):148-154.

36. Fisher L, Fisher A. Vitamin D and parathyroid hormone in outpatients with noncholestatic chronic liver disease. Clin Gastroenterol Hepatol. 2007;5(4):513-520. 